\title{
The Reformed tradition as public theology
}

\begin{abstract}
Author:
Vuyani S. Vellem ${ }^{1}$

Affiliation:

${ }^{1}$ Department of Dogmatics

and Christian Ethics,

University of Pretoria,

South Africa

Note:

This article originated

from a presentation at

the Kopanong Conference

Centre. It was a conference

on celebrating the Reformed

tradition within the auspices

of the World Communion of

Reformed Churches on 29

October 2011.
\end{abstract}

\section{Correspondence to:}

Vuyani Vellem

Email:

vuyani.vellem@up.ac.za

Postal address:

Private Bag X20, Hatfield

0028, South Africa

Dates:

Received: 04 Dec. 2012

Accepted: 03 Mar. 2013

Published: 03 May 2013

How to cite this article:

Vellem, V.S., 2013, 'The

Reformed tradition as public

theology', HTS Teologiese

Studies/Theological Studies

69(1), Art. \#1371, 5 pages.

http://dx.doi.org/10.4102/

hts.v69i1.1371

\section{Copyright:}

C 2013. The Authors.

Licensee: AOSIS

OpenJournals. This work

is licensed under the

Creative Commons

Attribution License.

Read online:
This article is a South African perspective of a Black African reflection on the publicity of Reformed faith. Whilst the notion of public theology is fairly new, the article argues, it is important to define the 'public' of the type of public theology to which Reformed faith and tradition could be linked. As a confessional tradition, Reformed faith is intrinsically public, the article demonstrates. The publicity of this tradition is however ambivalent and tainted. I attempt to show this by discussing two important tenets of the Reformed Tradition: sola scriptura and sola fide, within the festering wounds of Black African colonialism, apartheid and the hegemony of the neoliberal paradigm in the 21st century.

\section{Introduction}

My approach to the topic takes the Black African experience as a starting point to define the role of Reformed faith as public theology in the 21st century. I have decided to look at the main themes or tenets of Reformed faith: sola scriptura and sola fide to demonstrate how it is virtually impossible to avoid their distortions if the life experiences of the oppressed members of this tradition have any consequence and are important. I will begin by giving some highlights about my journey with the Reformed tradition which is not necessarily unique but is intended as a prism of the ambivalent role the tradition has had on Black African peoples. I then delve into a brief discussion of public theology before I deal with the two main themes of the tradition I have selected. My approach ultimately is to thread the Reformed tradition to the main challenges that I perceive to be pivotal for the tradition if it is to be a part of the life-giving archaeology of faith in the 21st century.

\section{An African experience of Reformed faith}

A few years ago, I was fortunate to stand in Calvin's pulpit in Geneva. I thought it was the best moment which provided me with all the blessings from my 'ancestor' of faith as I descended from that pulpit. Whether this might sound superstitious or not, in Africa we still visit the graves of our forebears for blessings, but also for counsel when we are troubled in our lives. I did the same thing when I was at St. Andrews in Scotland. It was such a joy for me to stand in John Knox's pulpit! At least I told myself that I had the rare opportunity to physically relate to the fathers of my Reformed faith by touching the things they had used themselves in their teaching of Reformed faith.

My desire to know more about Reformed faith arises from a history that was debilitated by the trappings of apartheid, itself a distortion of the teachings of Reformed faith rightfully declared a heresy by the Reformed community in 1982. No one can ever forget the role that Allan Boesak played in this regard, but more importantly, the use of Reformed faith itself in the struggle for liberation in South Africa. ${ }^{1}$ This historical ambivalence of the Reformed tradition in South Africa is a troublesome journey that any Black African person who is part of this family undertakes almost on a daily basis.

Since the demise of apartheid in 1994, the fall of the Berlin Wall and the collapse of the Soviet Union, the vestiges of what was once a distortion of this faith have continued to bedevil our public life notwithstanding the efforts and attempts since then to rid the country of the spell of apartheid. For years therefore, this ambivalent experience of Reformed faith in relation to my Black African experience aptly finds expression in the metaphorical statement that Gabriel Setiloane, (cited in Maluleke 2004) once used to describe a similar predicament:

For myself, first I am like someone who has been bewitched, and I find it difficult to shake off the

Christian witchcraft with which I have been captivated. (p. 186)

In attempting to deal with the spell of the distortions of the Reformed tradition I have gone further to consciously seek to reach Calvin without effacing Jacobus Elisa Johannes Capitein,

1.It is necessary to make this point as this paper continues from that tradition of the re-interpretation of Reformed faith for the liberation of the Black Africans even though the ambivalence of the tradition continues in the post-1994 political settlement. 
an African child who was sold at the age of seven and later became a chaplain in the 18th century of the slavery-infested West Coast of Africa. Coming nearer home, I find some healing from my captivation with the Reformed tradition when I recall 'the first ordained preacher of the Caffre race' in the words of Dr Anderson² of Scotland, Tiyo Soga, recently remembered and lauded by former President Thabo Mbeki (2011) when he said:

I believe that there can be no greater justification for us to be here today than that we have come to pay a tribute and indeed draw inspiration from one whom Dr Anderson accurately described as - a model African for the imitation and inspiration of his country men and women (p. 2).

Thabo Mbeki expressed these words at the occasion of the unveiling of the Tiyo Soga Memorial in Butterworth on the 09 September 2011. If Tiyo Soga is the model African we must imitate, an inspiration for us to be part of a Reformed Church in Africa therefore, my methodological approach to the topic at hand must now be clear. I cannot but reach Calvin and Geneva through Tiyo Soga and through the dungeons that kept Jacobus Elisa Johannes Capitein and his forebears under a Reformed Church building in Ghana. Tiyo Soga, who married a white woman from Scotland, is the quintessential epitome of the insult and degradation borne out of an encounter of Reformed faith by Black people. He is regarded as a father of Black and African theologies in South Africa.

Earlier in Ghana, the close affinity of the Reformed faith with slavery is depicted in the life of Jacobus Elisa Johannes Capitein. Of course André Biéler (2005:148-157), I must state at this very juncture, offers a lengthy exposition on Calvin's teachings on slavery to exonerate him, but the good exposition of Calvin will forever have to contend with the practical distortions and death-dealing experiences of Black African peoples. Similarly, the South African contradictory versions of the racial, oppressive experiences of many a Black person have been explained as being consequences of the distortions of Calvin's teachings and thus the Reformed tradition itself.

My task therefore, in order that the Reformed tradition can make a contribution to public life in Africa, cannot be attained without making the archaeology of the African experience, a la Mudimbe (1988), run 'upstream'. Whilst this might sound as fury to some, it is simply inevitable for me to run the symbols and history of Africa upstream as Africa, according to Achille Mbembe (2001:4), has been viewed as nothing, nothing at all. The Reformed tradition has to deal with the domination of the physical space of the African people, the taming of the mind of the African people and the subjection of the local economic histories of the African people to Western epistemological orders. With this broad understanding of my approach, I suggest that we now move to the notion of public theology and its relationship with the Reformed tradition, or faith.

\section{Reformed faith as public theology}

No doubt, in our Reformed faith, the roots of public theology are contained in its confessions and other documents that can be traced from the 16th century, including Calvin's teachings (Ferguson 2004:107). In our South African context, the Belhar Confession is a good example of the public nature of confessions in this tradition. In addition, the Reformed tradition has always gone beyond the boundaries of the Church in its quest to establish a civil polity based on the Word of God. To the extent that John Calvin's teachings covered almost all aspects of society and the need for a thoroughly going reform of the entire society, the Reformed faith has had to contend with what Biéler calls 'the myth of Calvinist theocracy.'

Biéler (2005:113) argues that Calvin only became a citizen of Geneva five years before his death to discount this myth. Biéler differentiates between two forms of theocracy and designates one as the 'hierocracy' in which government is in the hands of the clergy and the other 'bibliocracy', which subjects both the Church and the state to the Word of God.

In other words, the public role of Reformed faith cannot be viewed through the myth of theocracy as there is only one model at offer for the church's participation in public life. There have been a number of models of the church's participation in public life, such as the tensional model in which there is a tension between the church and the state; a secular model in which the role of the church, or religion is allegedly absent from public life; and others like the South African one, which is arguably neither secular nor religious, but constitutional, recognising the role of religion in public life, whilst holding the constitution as the supreme law of the country. It is quite important though to mention that these models, particularly the debate around church-state relations, have not been a luxury in our South African case, given the fact that apartheid was a Christian state, perhaps fathomed after the 'myth of Calvinist theocracy' as I have already indicated above. Nonetheless, the roots of the Reformed faith as public theology whether in a pejorative sense or not cannot be denied. One outstanding champion of the publicity of Reformed faith in South Africa is Allan Boesak whose work has thoroughly been within the contours of the Reformed faith and his understanding of the Lordship of Christ in creation.

The publicity of faith however, also needs us to define the notion of 'public' itself. For our purpose, I shall be very brief. I have argued elsewhere that the notion of 'public' in public theology is understood in different ways. ${ }^{3}$ When public, in 'public theology' is not clearly defined, it simply remains ambiguous and even more confusing. For me publicity is a comprehensive amalgam of differentiated spheres in public life held together to enhance life between themselves.

3.Cf. Vellem (in press) 'Isixeko: A counter-hegemonic form of liturgy with implications for public theology in South Africa'. 
As a result, the comprehensive appropriation of the Reformed faith in public life is public theology. However, how such an appropriation defines its understanding of the notion of 'public,' unavoidably qualifies the type of public theology the Reformed faith is viewed to be. ${ }^{4}$ Works such as Black and Reformed by Allan Boesak, the Accra Confession, and thus the work by Puleng LenkaBula, Choose life, act in hope and may others, are a particular form of public theology. In the same way as there are different views about the notion of public, there are inevitably different forms of public theology. Consequently, my view of Reformed faith as public derives from my view of Black theology as public theology that is rooted in a particular kind of a 'public', a Black non-person. There are many reasons for this but the most important one for our discussion is that the whole school of public theology is new. ${ }^{5}$ From this understanding of the public nature of Reformed faith I would like us to focus on the public challenges of the Reformed tenets of our faith in Africa today.

\section{Sola Scriptura}

André Biéler, like many other scholars of the Reformation, argues that the fundamental causes of the Reformation were religious (2005:9). In other words, if this thesis is clearly understood, within this context of a myriad forms of social disturbances that synchronised with the Reformation, one should reckon that two things gave impetus to it: the Bible in vernacular and justification by faith alone, sola scriptura and sola fide, of course not to the exclusion of other tenets of the Reformed faith. I perceive the Bible as a public tool and we know that in Africa alone, there are more than six hundred translations of the Bible and perhaps more, as this point was made by John Mbiti (1994:27) some years ago. He says, 'the Bible has continued to be read in Africa, and by 1990 was available in some 600 African languages', a point we cannot overlook to assert the centrality of the Bible in Africa.

In South Africa, Gerald West has recently made this point of the publicity of the Bible eloquently in his article entitled: 'Thabo Mbeki's Bible: the role of religion in the South African public realm after liberation'. Gerald West says the Bible has always been at the centre of the liberation struggle even though it has been categorised as a tool of oppression. We need not retell this obvious story about the abuse of the Bible in Africa and South Africa. West (2009:1) goes on to cite Takatso Mofokeng, that in 'the absence of a better storeroom of ideological and spiritual food', the Bible will continue to occupy a central role in the lives of the masses. By the way, the thrust of the article by Gerald West is to analyse how Thabo Mbeki tamed the Bible for his political ends in South Africa. Thabo Mbeki accordingly, 'clearly recognises that he cannot engage with his public unless he also engages substantially with their key texts, which include the Bible' (West 2007:21). The Bible as a key text of the struggling masses in South Africa and African in general, is public in this sense and really consigns publicity to the notion of sola scriptura.

4.The debate on the impossibility of a universal public theology is found in Storra and Morton (2004).

5.For this particular argument cf. Vellem (2007:238-239); Maluleke (2011:79-89).
The agenda of the Reformed faith however, cannot simply appropriate the doctrine of sola fide without realising that the ideological equation of the Bible to the Word of God has been viciously challenged by amongst others, Itumeleng Mosala (1989). Tinyiko Maluleke (1996) sums this matter up well for us:

I propose that the equation of the Bible with 'the Word of God' is not only naïve but it is a dangerous form of naïveté. Furthermore, I propose that this equation has been and will continue to be more debilitating for Black African theologies than any of the dangers highlighted by Bediako, Sanneh, and Mugambi (1995) combined. The equation of colonialism with Christianity if and where it has occurred, has done far less harm to Black and African theologies than the equation of the Bible with the Word of God. (p.12)

The point I am making here is that if sola scriptura is a fundamental tenet of our Reformed faith; the agenda of the Reformed heritage cannot be articulated without realising the danger that the equation of the Bible with the Word has done.

That the Bible remains a text of the struggling masses challenges our Reformed faith to journey with the masses in public life by protecting the text from being co-opted by the powerful elite and the hegemonies of the day in public life. If indeed Maluleke (1996) is correct to say colonialism's damage is far less than the equation of the Bible with the Word of God, then there is no Reformed agenda in Africa without liberating the Bible from the ideologies of the powerful for the liberation of this continent. This point will become more vivid when I deal with the notion of sola fide.

\section{Sola Fide: Justification by faith alone}

The teaching of justification by faith alone in Africa is even more ambivalent. I pitch my argument at the level of economic liberation in South Africa and the theological debates that are related to the Accra Confession and ipso facto, the current and dominant paradigm of neo-liberalism. I cannot proceed without acknowledging that the relationship of capitalism with the Reformed faith is a dicey one, neither the complicity of the Christian faith with capitalism. Thus Reformed faith itself cannot be ignored when the translation of this faith with its slogan, sola fide, reached the African continent. No one can refute the fact that most of the countries that are powerful capitalist blocs on the globe have a historical relationship with the Reformed faith as part of their foundations. In fact Terry Eagleton (2009) discusses the matter of the relationship between Christianity and the liberal discourse thoroughly in his book Reason, Faith E Revolution: Reflections on the God Debate. One cannot fail to see the traits of Reformed faith in the liberal discourse when the origins of the latter are traced.

What is sola fide in Africa where, as Jose Casanova (1994) eloquently puts it, the mind of an individual has become 'the temple of modern polytheism'? Casanova says today religion can be deciphered by the claim that 'my mind is my church'.

Reformed faith came to Africa with individualism and the attendant dichotomising logic in the context of a deathdealing culture, where the commodification of life and crass 
materialism are the order of the day, these are traits we can link with Reformed faith as Africans in South Africa. This slogan, viewed from the perspective of faith alone, is like a frantic public call by prophets of Baal ready to sacrifice life at the altar for as long as the Reformed faith is associated with neo-liberal capitalism. I am in actual fact not arguing capitalism against socialism. Not at all, my point is that capitalism is a form of faith, at worst; neo-liberal capitalism is driven by faith and has become a pseudo-religion that ravages the globe in the 21 st century.

The Reformed faith in Africa has to clearly make a choice. For Reformed African people, the Accra Confession is not anything less than an expression of their faith in agony. Being a Black person and Reformed is about a particular form of faith that has radically been experienced as transformational. The continuity or discontinuity of Black African Reformed faith with the Reformed heritage will be at its zenith for as long as the complicity of Reformed faith with neo-liberal capitalism remains unchanged. Cone (1975) has argued many years ago that faith is historical and must arise from the struggles of liberation by the poor. This is what justification by faith alone means for Africans who, for centuries, have been victims of exclusion paradoxically blessed by the same Reformed faith.

Moeletsi Mbeki (2011) in his recent publication argues that post-apartheid, Black political leaders are powerless as they are simply consumers of the economy rather than producers. He uses the concept of an enclave economy to describe how for centuries African people have been excluded from economic benefits and have continued to be so excluded even in post-colonial times. For me this is a matter of faith. If we ask to which Reformed faith we must belong: the one on top of the dungeons that kept the slaves, or the one in the dungeons of slavery, my choice goes with the latter.

Effectively, if Africans are not 'producers' of Reformed faith what is the justification of the consumption of a faith tradition that is evidently not devoid of bigotry in South Africa? The relationship of faith with economics is a crucial matter in so far as the location of Black African people as either consumers or producers is concerned. Indeed, at the turn of the 19th century, the Ethiopian movement was not only a response to ill relations between races, but was also a response to the fact that Black people were used as commercial value by the missionary enterprise - Mpambani Mzimba (a symbolic figure) - himself, a child of the Reformed tradition, once contended. The prevalence of the prosperity gospel, the violent defence of a crumbling economic order, the inequalities between the poor and the rich, creation that is groaning, leadership that suffers from a sophisticated form of inferiority complex in South Africa and in Africa, all these challenges are truly a matter of faith. Therefore, to deal with these complex challenges in Africa, a spirituality of liberation is urgently needed as an agenda for the Reformed faith in Africa. Sola fide might be a vital public tool for a liberating spirituality and the liberation of Reformed Theology a la John de Gruchy (1991) in Africa. Let me conclude my thoughts by citing from Tinyiko Maluleke (2008):
We find ourselves in a situation in which the colony continues even after the colonial period. We see this in the way in which women are regarded and dealt with. The violence in which we live is postcolonizing all of us, especially women and children. Similarly, the scourge of poverty in a world that has more than enough for all is another sign of the continuation of the colony. We are now faced not only with the scourge of HIV / AIDS but with devastating consequences of the interface between gender, between HIV / AIDS and poverty. Issues of identity and selfesteem that Biko and his colleagues occupied themselves with have returned in the form of sexuality and sexual orientation debates of our times. Indeed, I want to suggest that the very fact that our young seem to be forgetting the likes of Biko is a symptom of the problems we do not even acknowledge to have. In the atmosphere we live in, religion runs a risk of becoming opium both for the rich and the poor. (p. 124)

A clear picture of the African experience of the Reformed faith that was translated with devastating distortions must be seen for what it is: life and death.

Here is a significant point for me though. Even though we cannot exclude the possibility of Reformed faith having been part of the struggle against apartheid in South Africa as Dirk Smit (2007) argues, it is this faith and its traditions that must be continuously liberated. No one can do so however, without confronting the distortions, complicity, criticism and scepticism on the Reformed faith and how all these impinge on life giving in Africa. These challenges are a matter of faith; otherwise our Reformed faith runs the risk of becoming opium both for the rich and the poor.

\section{Conclusion}

My own journey, in this faith tradition and the experience of many other Black African people adequately demonstrates that there can be no Reformed tradition in South Africa or Africa without contending with the distortions and deathdealing effects it has had on this continent. As a public theology, Reformed faith must contend with the fact that there are many public theologies. From a Black African perspective, the Reformed tradition cannot proceed with complicity when faith itself is at stake in the 21st century. Sola scriptura cannot be an ideological instrument that individualises and dichotomises the experience of millions from their struggles. The struggles of the marginalised, particularly their struggle for economic liberation, the article argued, are a matter of faith, sola fide!

\section{Acknowledgements Competing interests}

The author declares that he has no financial or personal relationship(s) which may have inappropriately influenced him in writing this article.

\section{References}

Biéler, A., 2005, Calvin's economic and social thought, World Council of Churches, Geneva. PMCid:2212915

Boesak, A., 1984, Black and Reformed, Skotaville, Johannesburg.

Casanova, J., 1994, Public religions in the modern world, Chicago University Press, Chicago. Cone, J.H., 1975, God of the oppressed, The Seabury Press, New York. 
De Gruchy, J. W., 1991, Liberating reformed theology: A South African contribution to an ecumenical debate, Wm. B. Eerdmans Publishing, Grand Rapids.

Eagleton, T., 2009, Reason, faith \& revolution: Reflections on the God debate, Yale University Press, London.

Fergusson, D., 2004, 'The Reformed tradition and tolerance', in W. Storrar \& A.R. Morton (eds.), Public theology for the twenty first century, pp. 107-142, T\&T Clarke, New York/London.

Khabela, G., 1996, The struggle of the Gods, Lovedale Press, Alice.

LenkaBula, P., 2009, Choose life, act in hope, World Alliance of Reformed Churches, Geneva.

Maluleke, T., 1996, 'Black and African theologies in the new world', Journal of Theology for Southern Africa 96, 1-19.

Maluleke, T., 2004, 'African Christianity as African religion: Beyond the contextualization paradigm', in E.M. Conradie (ed.), African Christian theologies in transformation, pp. 181-191, EFSA, Stellenbosch.

Maluleke, T., 2008, 'May the Black God stand!: Biko's challenge to religion', in A. Mngxitama, A. Alexander \& N. Gibson (eds.), Biko lives! Contesting the legacies of Steve Biko, pp. 115-126, Palgrave Macmillan, New York.

Maluleke, T.S., 2011, 'The elusive public of theology: A response to William Storrar' International Journal of Public Theology 5, 79-89. http://dx.doi.org/10.1163/ $156973211 \times 543751$

Mbeki, M., 2011, Advocates for change: How to overcome Africa's challenges, Picador Africa, Johannesburg.
Mbeki, T., 2011, 'Tiyo Soga: A pioneer modern African intellectual who died in 1871' an Address at the unveiling of Tiyo Soga Memorial at Thuthura, Butterworth.

Mbembe, A., 2001, On the post colony, University of California Press, Berkeley.

Mbiti, J., 1996, 'The Bible in African culture', in R. Gibellini (ed.), Paths of African theology, pp. 27-39, SCM, London.

Mosala, I.J., 1989, Biblical Hermeneutics and Black theology in South Africa, Wm. B.Eerdmans, Grand Rapids.

Mudimbe, V., 1988, The invention of Africa, Indiana University Press, Bloomington.

Smit, D.J., 2007, Essays in public theology: Collected essays 1, Sun Press, Stellenbosch. Storrar, W.F., \& Morton, A.R., 2004, Public theology for the $21^{\text {st }}$ century: Essays in honour of Duncan B. Forrester, T\&T Clark, New York. PMid:15328749

Vellem, V.S., 2007, 'The symbol of liberation in South African public life: A Black theological perspective', PhD thesis, Dept. Systematic Theology and Ethics, University of Pretoria.

Vellem, V.S., 2010, 'On Black South African public theology in a Global Era', Theologia Viatorum 34(1), 101-119.

Vellem, V.S., (in press), 'Isixeko: A counter-hegemonic form of liturgy with implications for public theology in South Africa', in I. Mekoa \& M. Mapadimeng (eds.), Remaking ourselves: A reader in African Culture, 1, Saltry Print, Cape Town.

West, G.O., 2009, Religion and spirituality in South Africa, Thabo Mbeki's Bible, Univerity of KwaZulu-Natal Press, Pitermaritzburg. 